\title{
Effects of sediment mineralogy to high-iron content in the groundwater of Rrogozhina Aquifer (Western Albania)
}

\author{
Arjan BEQIRAJ* \& Enkeleida BEQIRAJ (GOGA) \\ Department of Earth Sciences, Polytechnic University of Tirana, Rruga Elbasani, Tirana, Albania
}

Received August 2011; accepted October 2011

Available online 12 October 2011

DOI: $10.5038 / 1937-8602.56 .2 .3$

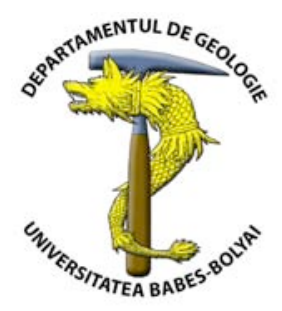

\begin{abstract}
The Rrogozhina Aquifer extending over the Pre-Adriatic Depression of Albania occurs under typically artesian conditions. The aquifer is hosted in Pliocene molasse formations and contains groundwater that mostly belongs to the $\mathrm{HCO}_{3}-\mathrm{Mg}-\mathrm{Ca}$ type. High $\mathrm{FeO}$ content (ranging from 0.2 to 2.5 wt.\%) characterizes the groundwater. The prevalence of ferrous iron is due to the lack of oxygen and the long underground residence time. Heavy minerals such as magnetite, epidote, garnet, titanite, amphibole, and pyroxene in the silt fraction of the sandstones might be responsible for the high $\mathrm{Fe}$ content in the groundwater.
\end{abstract}

Key words: Groundwater, Rrogozhina Aquifer, iron, mineralogical composition, Albania.

\section{INTRODUCTION}

Albania is rich in groundwater, mainly hosted by calcareous and alluvial formations. Due to its water potential, the Rrogozhina Aquifer (RA), which extends over a surface of $2100 \mathrm{~km}^{2}$, from Durresi in the north to Vlora in the south (Fig. 1) is ranked the second after the Quaternary alluvial aquifers in Albania. The high number of hydrogeological drillings that were performed during the last 50-60 years shows that the sandstone and conglomerate layers are to a different extent rich in groundwater. Many authors studied this aquifer aiming to clarify its lithology, stratigraphy, structure (Hyseni, 1995), hydrogeological features (Eftimi, 1984) and the groundwater quality. The extension of the Rrogozhina aquifer over the plain regions of the Pre-Adriatic Depression, which has recently experienced a demographic expansion, evidenced its importance for the water supply of the communities (Beqiraj et al., 2006, 2007). Most of the wells were drilled along the hill slopes, i.e. near the recharge zone where the quality of water is better (chemically) compared to other sectors of the aquifer extension.

\section{GEOLOGICAL AND HYDROGEOLOGICAL BACKGROUND}

The water-bearing sandstones and conglomerates of the Rrogozhina Aquifer belong to the Pliocene molasse formations which are transgressively deposited on mainly Miocene - Tortonian sediments. The lower part of the
Pliocene molasse consists of a clay section known as Helmesi formation, whereas the upper part is represented by the Rrogozhina formation. The lithological section of the latter consists of conglomerates, sandstones and clays. In the southern area, sandstones dominate, whereas in the north, the conglomerates prevail (Eftimi, 1984). In the frame of the folded Pliocene molasse formations, the clay formations of Helmesi constitute the nucleus of the anticlines, whereas the synclines are filled with coarse-grained sediments of the Rrogozhina formation (Hyseni, 1995). The Quaternary formations (10-150 m thick) above consist of clay, sandy clay, silt, silty sand, sand, gravel and pebbles. The waterbearing sandstones and conglomerates of the Rrogozhina formation outcrop on the hill slopes representing around $1 / 4$ of its general distribution area (Beqiraj et al., 2006). The pebbles of the conglomerates consist mainly of magmatic rocks and to a less extent of limestone, while their matrix is both carbonatic and clayey. According to the field observation and borehole sections, the thickness of the Rrogozhina formation ranges from $1000 \mathrm{~m}$ (Rrogozhina area) to $1700 \mathrm{~m}$ in the centre of the Karavasta syncline (Hyseni, 1995). The neotectonic movements have intensively affected the molasse formations.

The Rrogozhina Aquifer is a multilayered aquifer that occurs under typically artesian conditions (Eftimi, 1984). Its artesian character is conditioned by the following factors: i) the water-bearing sandstones and conglomerates are intercalated with impermeable clays; ii) they construct syncline forms; iii) the recharge zones have higher quota than the discharge zones. The sandstones and conglomerates 
show very heterogeneous permeability due to their different lithological composition, variable particle size, different degree of compactness, type of the cement, depth of the water-bearing layer, etc. All these parameters have conditioned an extremely variable yield of the wells (Eftimi, 1984). Beqiraj et al. (2007) found that the low values of the total dissolved solids (TDS) do not fit the corresponding high values of $K$ as it could be expected in the case of a heterogeneous aquifer.

The precipitations represent the main recharge source of the aquifer because of the vast outcrop of the sandstones and conglomerates (Fig. 1). Other recharge sources of the aquifer are the Quaternary alluvial aquifers above the rivers that intersect the aquifer transversally and the boundary aquifers. The groundwater drains as springs at the surface, or under the river gravel bed, or mainly under the sea bottom. The wells drilled through the Rrogozhina Aquifer represent a particular form of the groundwater drainage. In general, the mean values of the hydraulic parameters of the Rrogozhina Aquifer are low (Eftimi, 1984): transmissivity $\mathrm{T}=46$ $\mathrm{m}^{2} /$ day, hydraulic conductivity $\mathrm{K}=0.45 \mathrm{~m} /$ day, specific yield $\mathrm{q}=0.011 \mathrm{l} / \mathrm{s}$.

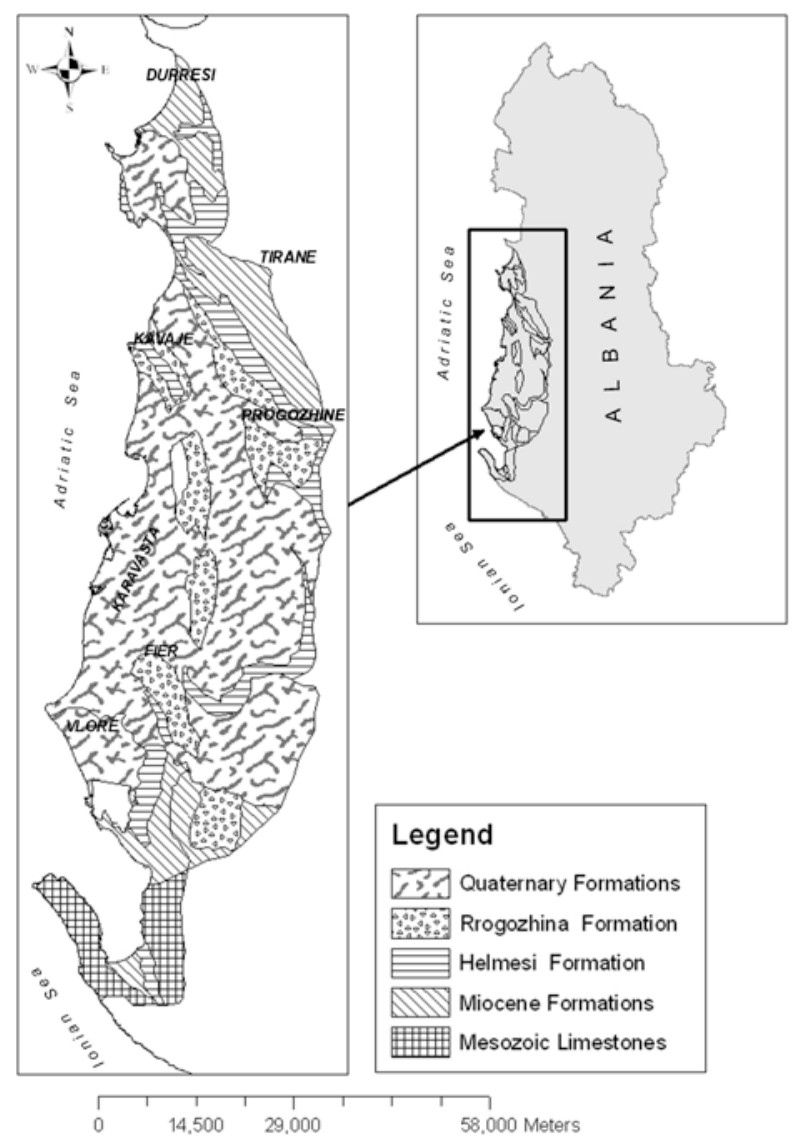

Fig. 1. Simplified geological map of the western part of Albania (after Beqiraj et al., 2006). The insert in upper right shows the position of the studied area within the Albanian territory.

\section{SAMPLES AND ANALYTICAL METHODS}

Forty representative sandstone samples were taken from outcrops and drilling cores. Sand, silt and clay fractions of these samples were obtained by sieve and hydrometric methods. Grain size analysis was carried out to separate sand from the mud using the $63-\mu \mathrm{m}$ sieve The silt and clay fractions were obtained with a hydrometer, in accordance with the ASTM C775-79 (1989).
The mineralogical composition of thin sections obtained from the sand fraction was studied by optical microscopy in polarized light. Clay and silt samples were examined by $\mathrm{X}$ ray diffraction (XRD). The patterns were recorded in a $5^{\circ}$ to $120^{\circ} 2 \theta$ interval, by a curved detector INEL CPS 120 and a Co anticathode with $\lambda_{\mathrm{CoK} \alpha 1}=0.70926 \AA$. Glycol ethylene treated (up to $60^{\circ} \mathrm{C}$ for $2 \mathrm{hrs}$ ) and non-treated oriented slides were also analyzed, in order to distinguish the expandable minerals.

Thirty-two groundwater samples were tested for the main chemical composition of the water by titration and colorimetric methods. Only 18 samples out of 32 were tested for the iron content, with a 6600 UV-VIS spectrophotometer. The accuracy was $0.01 \mathrm{mg} / \mathrm{l}$.

\section{RESULTS AND DISCUSSIONS}

\section{Hydrochemistry}

The groundwater shows variable geochemical composition due to different mineralogical features of the host rocks, the vast extension of the aquifer, the variable geological and hydrogeological features, the relationship with boundary aquifers and seawater, the relation of the tested groundwater with respect to recharge and discharge zone and possibly its occurrence deep within the aquifer. However, the mineralogical composition of the waterbearing sandstones and conglomerates that contain carbonates and iron-bearing magmatic and metamorphic minerals argues for the $\mathrm{HCO}_{3}{ }^{-} \mathrm{Mg}-\mathrm{Ca}$ hydrochemical groundwater type. Such a geochemical composition characterizes the groundwater of the Rrogozhina Aquifer as a chemically immature one (Allen and Suchy, 2001). It is a fresh groundwater, of which chemical composition mainly plots near the center of the Piper diagram (Fig. 2). The immature nature of the groundwater composition is in agreement with the depth of the sampled water $(100 \mathrm{~m}$ to $250 \mathrm{~m}$ below surface) and consequently the groundwater has similar $\mathrm{pH}$ (7.0-8.5), total dissolved solids (500-800 mg/l) and general hardness $\left(11-25^{\circ} \mathrm{dH}\right)$ to the surface water (Beqiraj and Kumanova, 2010). Dissolution of some minerals, such as calcite and dolomite seems to be the major process leading to the groundwater composition. Other hydro-chemical types are also significant and are mainly related with the $\mathrm{Na}$ and $\mathrm{Fe}-\mathrm{Mg}$ enrichment in water through cation exchange process between the groundwater and clay or magmatic minerals, respectively. The effects of this process in the formation of the groundwater composition are shown in Fig. 2, where certain water samples plot close to the centre of the $\mathrm{Na}+\mathrm{K}-\mathrm{Ca}+\mathrm{Mg}$ rhombic diagram. The lack of the more evolved or highly evolved groundwater compositions of the analyzed samples can be explained by the weak influence of the deep groundwater and sea water.

At the $\mathrm{pH}$ commonly encountered in groundwater (7.0$8.5), \mathrm{HCO}_{3}^{-}$is the dominant carbonate species present. In general, up to the above-drilled depth $(100-250 \mathrm{~m})$, all the hydrochemical parameters of the groundwater fit the Albanian and EU limits for the potable water (WHO, 1970). In some cases, $\mathrm{NH}_{4}^{+}, \mathrm{H}_{2} \mathrm{~S}, \mathrm{Cl}^{-}$, etc. are in concentrations higher than the limits of drinking water. It was found that the groundwater can maintain TDS values less that $1 \mathrm{mg} / 1$ up to a depth of 400 to $500 \mathrm{~m}$ according to the well position with respect to the recharge and discharge zone (Beqiraj et al., 2006). 


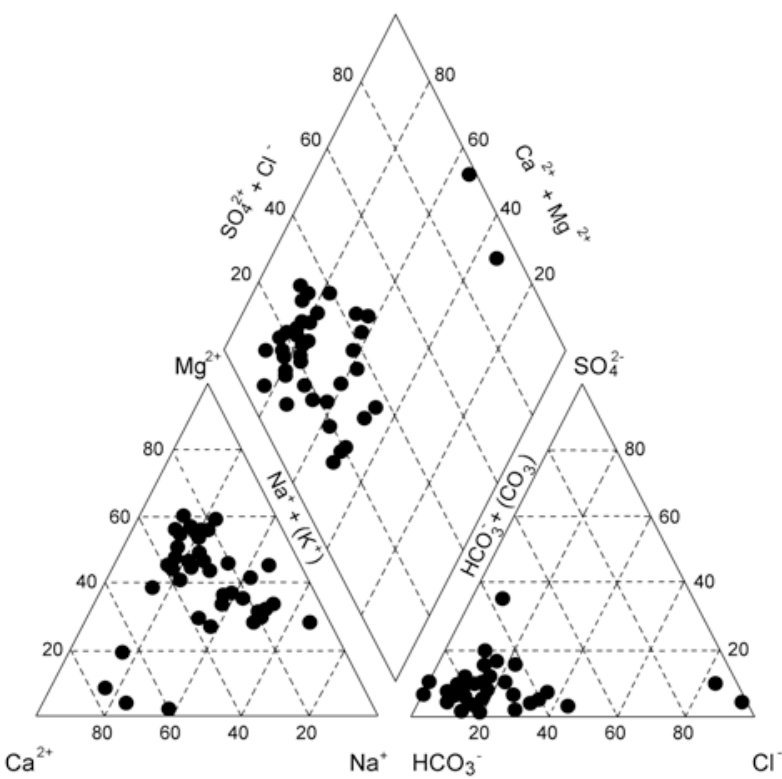

Fig. 2. Piper plot of geochemical data for the Rrogozhina groundwater (Piper, 1953).

\section{Role of iron in the Rrogozhina groundwater}

As a chemical species, iron can exist in the environment in several different forms. Iron in soils typically occurs in the more oxidized $\mathrm{Fe}^{3+}$ form as opposed to the $\mathrm{Fe}^{2+}$ form. In the oxidized form, the iron is relatively immobile and stays as part of the soil matrix. When reducing conditions convert some of the oxidized iron into a reduced form $\left(\mathrm{Fe}^{3+} \rightarrow\right.$ $\mathrm{Fe}^{2+}$ ), the iron may be released from the soil matrix into the groundwater (Zachara et al., 2001; Benner et al., 2002; Pedersen et al., 2005). The Rrogozhina Aquifer is known for the high concentration of iron (Eftimi, 1984). Most of the groundwater samples from the wells drilled through the sandstone-conglomerate sequences contain more than 0.2 wt.\% FeO (Table 1; see also Beqiraj et al., 2006).

The $\mathrm{FeO}$ concentration in groundwater ranges from 0.2 wt. $\%$ up to 2.5 wt. $\%$, but most of them fall within the 0.5 to $1.0 \mathrm{wt} . \%$ interval. Iron occurs as ferrous iron $\left(\mathrm{Fe}^{2+}\right)$, which is soluble as a cation (Appelo and Postma, 1996). In fact, the dissolved ferrous iron represents the only oxidation state of iron that was found in Rrogozhina groundwater, as shown by the colorless water extracted from the wells. This suggests reducing conditions in the confined aquifer of Rrogozhina due to the water interaction with soil organics and minerals; the first are oxidized while the second ones are reduced (Reddy and Cameselle, 2009).

Table 1. Major ion contents in the groundwater of the Rrogozhina Aquifer. All ion contents and TDS are in $\mathrm{mg} / \mathrm{l} ; \mathrm{TDS}=\mathrm{Na}^{+}+\mathrm{K}^{+}+\mathrm{Ca}^{2+}+$ $\mathrm{Mg}^{2+}+\mathrm{Fe}^{2+}+\mathrm{HCO}_{3}^{-}+\mathrm{SO}_{4}{ }^{2-}+\mathrm{Cl}^{-}+\mathrm{H}_{2} \mathrm{SiO}_{3} ; \mathrm{GH}=\left\{2.5^{*}[\mathrm{Ca}]+4.1^{*}[\mathrm{Mg}]\right\} / 17.8 ;$ GH (general hardness) is in ${ }^{\circ} \mathrm{dH}$.

\begin{tabular}{|c|c|c|c|c|c|c|c|c|c|c|c|}
\hline Sample no. & $\mathrm{Na}^{+}+\mathrm{K}^{+}$ & $\mathrm{Ca}^{2+}$ & $\mathrm{Mg}^{2+}$ & $\mathrm{Fe}^{2+}$ & $\mathrm{HCO}_{3}^{-}$ & $\mathrm{SO}_{4}{ }^{2-}$ & $\mathrm{Cl}^{-}$ & $\mathrm{H}_{2} \mathrm{SiO}_{3}$ & TDS & $\mathrm{GH}$ & $\mathrm{pH}$ \\
\hline $\mathrm{Rr}-1$ & 35.91 & 69.14 & 25.54 & 3 & 301.95 & 27.98 & 152.65 & 18.16 & 634.33 & 15.85 & 7.79 \\
\hline $\mathrm{Rr}-2$ & 198.26 & 39.68 & 40.33 & 2.5 & 491.05 & 19.75 & 181.05 & 9.08 & 981.7 & 14.84 & 7.71 \\
\hline Rr-3 & 220 & 60 & 11 & 2.7 & 312 & 25.5 & 282 & 8.85 & 922.05 & 11 & 7.67 \\
\hline Rr-4 & 220 & 60 & 22 & ND & 362.6 & 40.3 & 177.5 & 8.92 & 891.32 & 14 & 7.83 \\
\hline Rr-5 & 93.4 & 38.1 & 52.3 & 0.3 & 346.3 & 9.9 & 156.2 & 10.4 & 706.9 & 17.39 & 7.95 \\
\hline $\operatorname{Rr}-6$ & 35.91 & 70.14 & 38.41 & 0.55 & 285.48 & 12.76 & 203.9 & 15.75 & 662.9 & 18.82 & 7.6 \\
\hline $\mathrm{Rr}-7$ & 12.45 & 77.27 & 63.69 & 0.8 & 540.46 & 71.6 & 56.74 & 3.89 & 826.9 & 25.54 & 8.2 \\
\hline $\mathrm{Rr}-8$ & 30.6 & 59.5 & 28 & ND & 256.2 & 20.6 & 62.1 & 28.5 & 485.5 & 14.75 & 7.3 \\
\hline Rr-9 & 28.8 & 53.2 & 72 & ND & 372.1 & 42.8 & 71 & 22.2 & 662.1 & 23.99 & 8.7 \\
\hline $\mathrm{Rr}-10$ & 33.5 & 124 & 22.2 & 0.2 & 400.1 & 88.4 & 39.6 & 19.5 & 727.5 & 22.51 & 7.6 \\
\hline Rr-11 & 51.7 & 60.9 & 81.6 & ND & 561.2 & 58.4 & 56.08 & 25.9 & 895.78 & 27.33 & 7.8 \\
\hline $\mathrm{Rr}-12$ & 71.3 & 39.1 & 52 & 0.1 & 464.8 & 26.7 & 40.8 & 12.32 & 707.12 & 17.41 & 7.8 \\
\hline $\mathrm{Rr}-13$ & 77.7 & 41.9 & 39 & 0.1 & 376.9 & 47.7 & 53.2 & 9.4 & 645.9 & 11.81 & 8 \\
\hline $\mathrm{Rr}-14$ & 45.31 & 48.36 & 60.6 & 0.21 & 488 & 24.82 & 31.69 & 15.56 & 714.55 & 20.69 & 8 \\
\hline $\mathrm{Rr}-15$ & 36.8 & 46.6 & 59.9 & ND & 452.6 & 28.8 & 30.2 & 6.5 & 661.4 & 20.36 & 7.8 \\
\hline $\mathrm{Rr}-16$ & 62.79 & 51.77 & 50.65 & 0.87 & 474.58 & 34.54 & 35.5 & 10.3 & 721 & 18.95 & 7.7 \\
\hline $\mathrm{Rr}-17$ & 49.9 & 51.9 & 56.1 & 0.5 & 450.8 & 51 & 33.7 & 11.7 & 705.6 & 20.22 & 7.8 \\
\hline $\mathrm{Rr}-18$ & 45.31 & 48.36 & 60.6 & 0.21 & 488 & 31.69 & 24.82 & 15.56 & 714.55 & 20.69 & 8 \\
\hline Rr-19 & 62.79 & 51.77 & 50.65 & ND & 474.58 & 34.57 & 35.5 & 11.6 & 721.46 & 18.95 & 7.9 \\
\hline Rr-20 & 50.6 & 66.16 & 56 & 0.85 & 463.6 & 34.98 & 63.83 & 12.2 & 748.22 & 22.2 & 7.6 \\
\hline $\operatorname{Rr}-21$ & 61.2 & 77 & 66 & 0.5 & 4.45 & 27.6 & 147.5 & 3.9 & 388.15 & 26.21 & 7.8 \\
\hline Rr-22 & 109.71 & 70.14 & 58.25 & 0.15 & 408.7 & 18.1 & 198.58 & 19.46 & 883.09 & 23.27 & 8.3 \\
\hline $\operatorname{Rr}-23$ & 18.6 & 51 & 94.7 & ND & 527 & 79.8 & 30.1 & 14.7 & 815.9 & 28.92 & 8.5 \\
\hline $\operatorname{Rr}-24$ & 73.83 & 48.14 & 76.87 & ND & 562.42 & 64.12 & 55.02 & 8.7 & 889.1 & 24.89 & 7.7 \\
\hline $\operatorname{Rr}-25$ & 50.6 & 44.3 & 67.8 & ND & 456.3 & 41.5 & 53.2 & 31.1 & 744.8 & 21.78 & 8.8 \\
\hline $\operatorname{Rr}-26$ & 95.9 & 78.8 & 36 & ND & 418.5 & 81.5 & 88.7 & 38.9 & 838.3 & 19.29 & 8.6 \\
\hline $\operatorname{Rr}-27$ & 152.2 & 53.2 & 46.5 & ND & 639.3 & 6.6 & 88.7 & 22 & 1008.5 & 18.2 & 8.5 \\
\hline $\mathrm{Rr}-28$ & 63.5 & 58.7 & 59 & ND & 518.5 & 46.1 & 87.5 & 47.9 & 881.2 & 22.01 & 7.8 \\
\hline Rr-29 & 114.54 & 25.55 & 38.74 & ND & 370.89 & 15.64 & 108.15 & 17.6 & 691.11 & 12.54 & 7.7 \\
\hline $\mathrm{Rr}-30$ & 28.29 & 60.45 & 65.61 & 0.62 & 516.06 & 21.4 & 28.4 & 13.45 & 734.28 & 23.6 & 7.5 \\
\hline
\end{tabular}


The long $(>20 \mathrm{~km})$ distance between the recharge and the discharge zones along with low (0.3-2.5 m/day) hydraulic conductivity of the medium (Eftimi, 1984) has caused a gradual depletion in $\mathrm{O}_{2}$ down to anaerobic conditions. In general, such aquifers as Rrogozhina, are characterized by low levels of oxygen (Christenbury, 1990). When oxygen in groundwater is consumed, oxidation may still occur, but in this case the oxidizing agents are $\mathrm{NO}_{3}{ }^{-}$, $\mathrm{MnO}_{2}$, and $\mathrm{Fe}(\mathrm{OH})_{3}$. In the same time, the water reduction/oxidation state progresses from nitrate reducing to manganese or iron reducing, or sulfate-reducing conditions and eventually to methane-reducing conditions. These will result in the production of $\mathrm{NH}_{3}, \mathrm{Mn}^{4+}, \mathrm{Fe}^{2+}, \mathrm{H}_{2} \mathrm{~S}$, and $\mathrm{CH}_{4}$, respectively (Reddy and Cameselle, 2009). The same situation was found in the RA as shown by the presence of $\mathrm{Fe}^{2+}$ in the groundwater over the whole extension of the

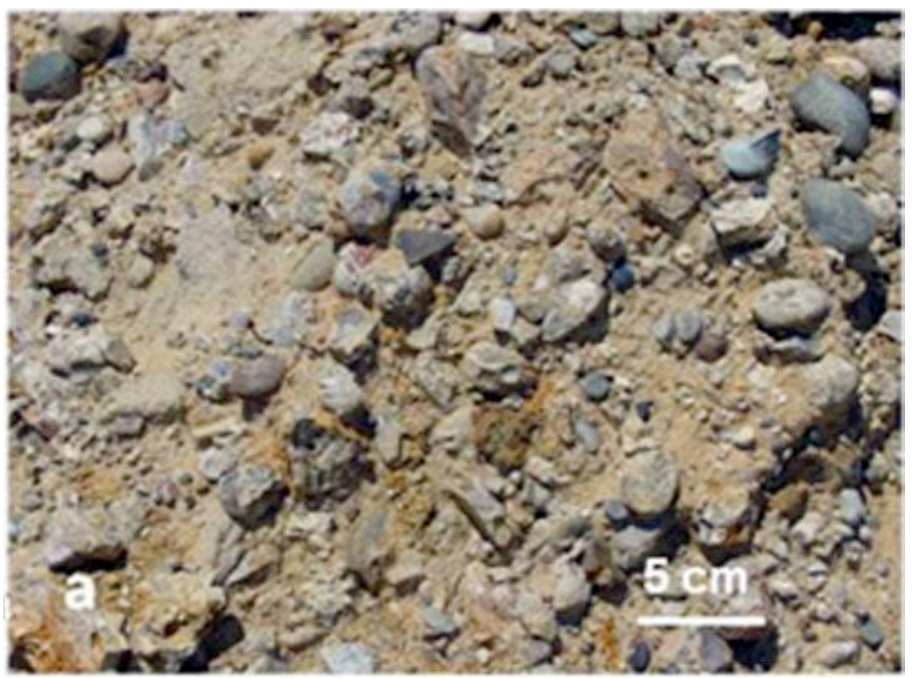

aquifer along with some significant contents of $\mathrm{NH}_{3}, \mathrm{H}_{2} \mathrm{~S}$ and $\mathrm{CH}_{4}$ in different wells (Eftimi, 1984; Beqiraj et al., 2006).

In addition, the long residence time of the groundwater favored their enrichment in $\mathrm{Fe}^{2+}$ and other constituents. More iron enters into solution as the age of groundwater increases because it tends to be released progressively from the geological materials. Water containing ferrous iron is clear and colorless. In contact with the air, the colorless ferrous iron bearing water gets a reddish color because the oxygen reacts with the dissolved iron to form insoluble ferric oxide (Gruett, 1993) - also known as iron oxide or "red rust". The intensity of reddish color is proportional with both iron content in water and time of exposure to air. In general, the sandstones are more reddish than conglomerates (Fig. 3a, b).

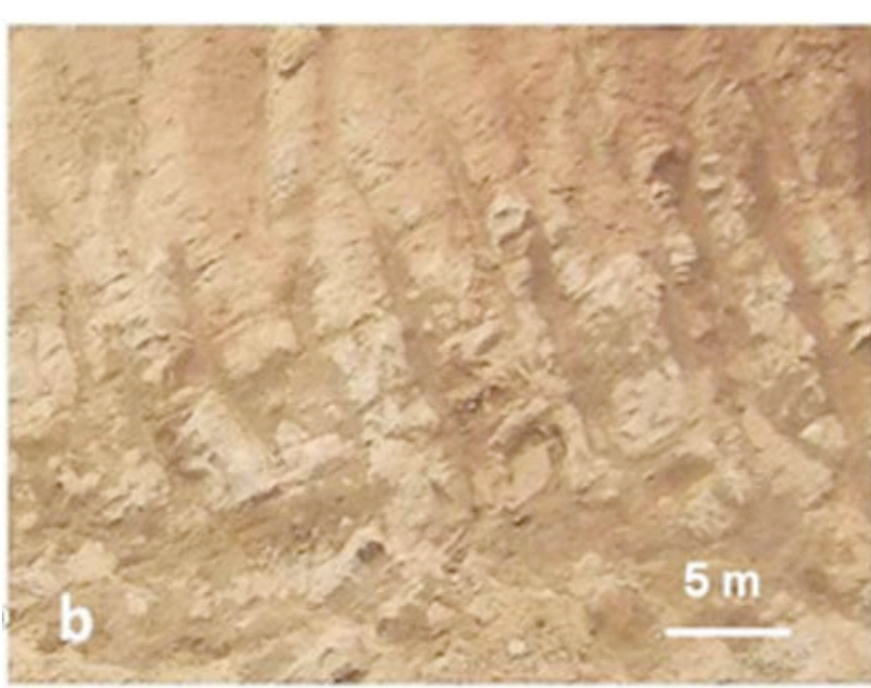

Fig. 3. a) Conglomerate (a) and sandstone (b) cropping out on the slopes of the Fieri and Durresi hills. The reddish color of the sandstone is due to the high Fe content.

Regarding the heterogeneous distribution of $\mathrm{Fe}$ in the groundwater some rough regularity can be found. Iron is more frequent and higher in sandstone-related groundwater as it is shown by the positive correlation between the iron content in groundwater and the sandstone thickness in the according section of the wells (Table 2; Fig. 4). A similar conclusion can be drawn comparing the iron content in the corresponding groundwater from the southern part (region of Karavasta) and the northern part (region of Kavaja), respectively (Fig. 1). As discussed above, the geological section of the southern part consists mainly of sandstone, whereas in the northern part of the aquifer the conglomerate dominates. Consequently, the groundwater from the Karavasta contains from 0.88 wt. $\%$ up to 11.49 wt. $\% \mathrm{FeO}$, whereas in the Kavaja area it has 0.33 wt.\% to 2.93 wt.\% $\mathrm{FeO}$.

Table 2. The variation of $\mathrm{FeO}$ content (in wt.\%) versus sandstone layer thickness $H$ (in $\mathrm{m}$ ).

\begin{tabular}{|l|l|l|l|l|l|l|l|l|l|}
\hline Sample \# & Rr2/1 & Rr4/1 & Rr5/1 & Rr6/1 & Rr8/1 & Rr11/1 & Rr12/1 & Rr13/1 & Rr14/1 \\
\hline $\mathrm{FeO}$ & 0.8 & 0.2 & 0.2 & 0.3 & 0.8 & 0.7 & 0.1 & 0.2 & 1 \\
\hline $\mathrm{H}$ & 62.6 & 19.2 & 40.2 & 7.7 & 47.1 & 34.5 & 6.6 & 35 & 74 \\
\hline
\end{tabular}

\begin{tabular}{|l|l|l|l|l|l|l|l|l|l|}
\hline Sample \# & Rr16/1 & Rr17/1 & Rr18/1 & Rr20/1 & Rr21/1 & Rr-25/1 & Rr26/1 & Rr27/1 & Rr32/1 \\
\hline $\mathrm{FeO}$ & 0.12 & 0.1 & 0.2 & 0.9 & 0.4 & 0.62 & 0.4 & 0.4 & 0.2 \\
\hline $\mathrm{H}$ & 9 & 5 & 36.6 & 64.5 & 49.4 & 23.6 & 47.1 & 50 & 40 \\
\hline
\end{tabular}

The sand, silt and clay fractions of the sandstone (according to Unified Soil Classification System - USCS) show different mineralogical composition. The sand fraction (between 0.075 and $4.5 \mathrm{~mm}$ particle size) consists of quartz (59\%), feldspar (19\%) and muscovite (20\%) (Fig. 5a), whereas the clay fraction $(<0.002 \mathrm{~mm}$ particle size $)$ is composed of montmorillonite (42\%), illite (19\%) and kaolinite (20\%) (Fig. 5b). Magnetite (48\%), epidote (15\%), garnet $(8 \%)$ as well as titanite, amphibole and pyroxene (Fig. 5c) form the silt fraction $(0.002-0.075 \mathrm{~mm}$ particle size). The predomination of iron-bearing minerals in the silt fraction of the sandstone supports the opinion that the iron 
content in groundwater is mainly related to the silty material. Nevertheless, a contribution of $\mathrm{Fe}$ minerals adsorbed by montmorillonite and/or illite can be also considered.

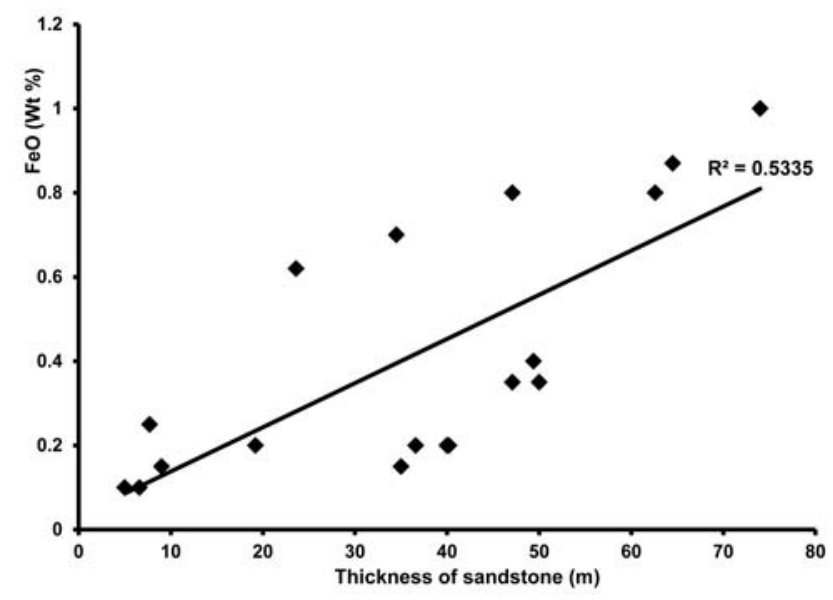

Fig. 4. Diagram of iron content variation in the groundwater versus sandstone layer thickness.

Postma and Brockenhuus-Schack (1987) found that amphiboles and pyroxenes in a sandy aquifer show distinct dissolution features. Thus, these minerals might be an important source of $\mathrm{Fe}^{2+}$ in groundwater. In general, the dissolution of $\mathrm{Fe}^{2+}$-bearing silicates is much faster in anoxic than in oxic conditions (Appelo and Postma, 1996). This can also be expected within the Rrogozhina aquifer. The inhomogeneous concentration of iron in the groundwater sampled in different places of the aquifer extension most likely reflects the variable particle size of the sandstone. The primary content of the sedimentation environment can be regarded as another source of the $\mathrm{Fe}$ in the groundwater. Both ferrous and ferric iron is present in many minerals, especially within sandstones, where $\mathrm{Fe}^{2+}$ is found in clay minerals, carbonates, and sulfides. $\mathrm{Fe}^{3+}$ occurs in hydrous and anhydrous oxides (Pettijohn et al., 1987). Oxides precipitate under the most oxidizing conditions, which correspond to the sedimentation environment of continental shelf and upper continental slope, as the case of the Rrogozhina formation (Hyseni, 1995).

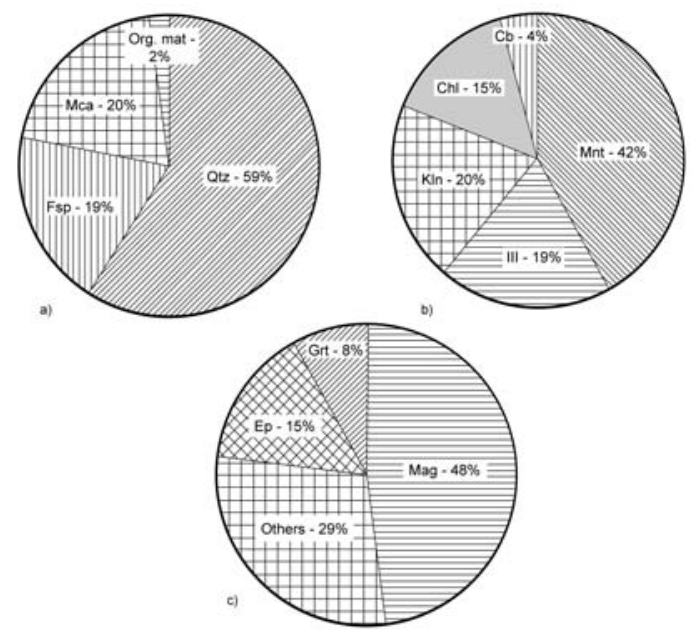

Fig. 5. Mineralogical composition of sand (a), clay (b), and silt (c) fractions of sandstone. Abbreviations: Qtz-quartz, Fsp-feldspar, Mca-mica, Org. mat. - organic material, Mnt-montmorillonite, Ill-illite, Kln-Kaolinite, Chl-chlorite, Cb-carbonate mineral, Mag - magnetite, Ep - epidote, Grt-garnet, Others - chromite, zircon, titanite, amphibole, pyroxene.

\section{CONCLUSIONS}

The Rrogozhina Aquifer consists of water-bearing sandstones and conglomerates, which belong to the Pliocene molasse formations of the Albanian Pre-Adriatic Depression. This typically artesian, multi-layered aquifer shows a variable permeability. The precipitations represent the main recharge source of the aquifer, whereas its groundwater mainly discharges under the seawater. The groundwater of Rrogozhina Aquifer belongs to the $\mathrm{HCO}_{3}{ }^{-}$ $\mathrm{Mg}-\mathrm{Ca}$ type due to the mineralogical composition of the porous medium, which contains iron-bearing magmatic and metamorphic minerals, as well as carbonates. The general mineralization is medium to high $(500-800 \mathrm{mg} / \mathrm{l})$ due to long water/rock contact time. The hardness that ranges from 11 to $25^{\circ} \mathrm{dH}$, roughly correlates with it. The groundwater of the Rrogozhina Aquifer contains high concentrations of iron that ranges from $0.2 \mathrm{wt} . \%$ up to 2.5 wt.\% FeO. Both, the confined conditions and the long residence time of the groundwater favored this enrichment. Iron is more frequent and higher in the sandstone-related groundwater than in that related to conglomerates. Consequently, the groundwater in the southern part of the aquifer has highest concentration of iron. The predomination of Fe-rich minerals such as magnetite, epidote, garnet, titanite, amphibole, and pyroxene in the silt fraction of the sandstone points to the latter as the main source of the iron in the groundwater. The montmorillonite and illite can also contribute to iron enrichment in groundwater via cation exchange process.

Aknowledgements. This research was funded by the Academy of Sciences of Albania. The authors highly appreciate the contribution of two anonymous reviewers whose comments and suggestions significantly improved the manuscript. The authors wish to acknowledge Dr. Xh. Kumanova for her support in analyzing the water samples.

\section{R E F E R E N C E S}

Allen, D., Suchy, M. 2001, Geochemical evolution of groundwater on Saturna Island, British Columbia. Canadian Journal of Earth Science, 38: 1059-1080.

Appelo, C.A.J., Postma, D. 1996, Geochemistry, groundwater and pollution. A.A. Balkema, Rotterdam, 649 p.

Benner, S., Hansel, C., Wielinga, B., Barber, T. \& Fendorf, S. 2002, Reductive dissolution and bioremediation of iron hydroxide under dynamic flow conditions. Environmental Science and Technology, 36 (8): 1705-1711.

Beqiraj, A., Hyseni, A., Marku, S. \& Saraçi, M. 2006, Assessment of quality and quantity of underground water in the Rrogozhina Aquifer as a water supply potential source for the rural zones within it. Faculty of Geology and Mining, Polytechnic University of Tirana, 108 p (in Albanian).

Beqiraj, A., Hyseni, A., Leka, Gj. \& Mata, M. 2007, Geological-structural aspects of the Rrogozhina aquifer (Albanian pre-Adriatic Depression). In Abstract book of the Management of geomining resources Workshop, Kosovo, p. 57.

Beqiraj, A., Kumanova, Xh. 2010, Geochemistry of groundwater of Rrogozhina aquifer (Western Albania). $7^{\text {th }}$ ISEMG Symposium, Adana, Turkey, p. 87. 
Christenbury, J.H. 1990, Iron and manganese. WQL 9. South Carolina Coop. Extens. Serv. Clemson University. Clemson, SC., 35 p.

Eftimi, R. 1984, Permeability features of Rrogozhina formation. Bulletin of Geological Sciences, 3: 57-73 (in Albanian).

Gruett, G. 1993, Removing problem iron. Water Technology, 16 (3): 48-51.

Hyseni, A. 1995, Structure and geodynamic evaluation of Pliocene molasses of pre-Adriatic Depression. Unpubl. $\mathrm{PhD}$ Thesis. Polytechnic University of Tirana. 175 p. (in Albanian).

Reddy, K.R., Cameselle, C. 2009, Electrochemical remediation technologies for polluted soils, sediments and groundwater. Wiley \& Sons, $732 \mathrm{p}$.

Piper, A.M. 1953, A graphic procedure in the geochemical interpretation of water analysis. American Geophysical Union Transactions, 25 (6): 914-928.
Pedersen, H., Postma, D., Jakobsen, R. \& Larsen, O. 2005, Fast transformation of iron oxyhydroxides by the catalytic action of aqueous $\mathrm{Fe}(\mathrm{II})$. Geochimica et Cosmochimica Acta, 69 (16): 3967-3977.

Pettijohn, F.J., Potter, E. \& Siever, R. 1987, Sand and sandstone. Springer-Verlag Publishing Inc., New York, $553 \mathrm{p}$.

Postma, D., Brockenhuus-Schack, B.S. 1987, Diagenesis of iron in proglacial sand deposits of late- and postWeichselian age. Journal of Sedimentary Petrology, 57: 1040-1053.

WHO, 1970. European standards for drinking water. $2^{\text {nd }}$ ed., Geneva, 56 p.

Zachara, J., Fredrickson, J., Smith, S. \& Gassman, P. 2001, Solubilization of Fe (III) oxidebound trace metals by a dissimilatory $\mathrm{Fe}(\mathrm{III})$ reducing bacterium. Geochimica et Cosmochimica Acta, 65 (1): 75-93. 